\title{
Human hepatocyte nuclear factor-1ß (HNF1B) 1968A/G polymorphism
}

\begin{abstract}
We found a novel $\mathrm{A} \rightarrow \mathrm{G}$ change at nucleotide 1968 within the $3^{\prime}$-untranslated region of the $H N F 1 B$ gene encoding the hepatocyte nuclear factor- $1 \beta$. The $H N F 1 B$ $1968 \mathrm{~A} / \mathrm{G}$ polymorphism could be detected by digestion with endonuclease MspI. The frequency of the $H N F 1 B$ 1968G allele was 0.060 in Caucasians and 0.129 in Canadian Oji-Cree. Because of the importance of the $H N F 1 B$ gene product in the regulation of transcription of several hepatic proteins, this polymorphism may be useful in the study of associations with metabolic phenotypes such as diabetes.
\end{abstract}

Key words Diabetes · Gene regulation · Transcription factor

\section{Introduction}

Human hepatocyte nuclear factor-1 $\beta$ (HNF-1 $\beta$ ) is a liverspecific, but not liver-restricted, transcription factor, which shares homology with hepatocyte nuclear factor- $1 \alpha$ (HNF$1 \alpha$ ) in three important functional regions, including the homeo domain and the dimerization domain (Bach et al. 1991). These two transcription factors can form heterodimers in vitro, and may be important determinants of tissue specificity of expression of a variety of target genes, including albumin, fibrinogen, and some enzymes involved in carbohydrate and energy metabolism (Bach et al. 1991). An important role for the $H N F 1 B$ gene product in carbohydrate and energy metabolism has been further suggested by the observation of Horikawa et al. (1997), who found a nonsense mutation (R177X) in the HNF1B gene in a subject with diabetes. Thus, the $H N F 1 B$ gene is an important candidate gene for diabetes and its related phenotypes.

H. Cao $\cdot$ R.A. Hegele $(\bowtie)$

Blackburn Cardiovascular Genetics Laboratory, John P. Robarts Research Institute, 406-100 Perth Drive, London, Ontario, Canada N6A 5K8

Tel. +1-519-663-3461; Fax +1-519-663-3789

e-mail: robert.hegele@rri.on.ca
The HNF1B gene has been mapped to chromosome 17q22 (Abbott et al. 1990). The availability of a marker for the $H N F 1 B$ gene would be useful for the study of its possible association not only with diabetes but also with metabolic phenotypes related to insulin resistance, such as obesity and hypertension. In the course of DNA sequencing of all of the coding regions and the $5^{\prime}$ - and $3^{\prime}$-untranslated regions of the $H N F 1 B$ gene in a Canadian aboriginal subject with type 2 diabetes, we identified a novel, previously unreported $A \rightarrow G$ change at nucleotide 1968 , which is contained within the $3^{\prime}$-untranslated region of exon 9 .

\section{Polymorphism and allele frequency}

Primers for the polymerase chain reaction (PCR). For PCR, we used the following primers:

HNF1B-1968F 5'-TCATCTCCCTTAGAGAAGCCAA-3'

HNF1B-1968R 5'-TGTGGCAATACTGCATAGAAGG-3'

MspI polymorphism. The PCR fragment size was $320 \mathrm{bp}$. Digestion of the less common $1968 \mathrm{G}$ allele produced two smaller fragments, with sizes of 204 and 116bp. Digestion of the more common 1968A allele produced a single 320-bp fragment.

Chromosomal localization. The human HNF1B gene has been localized to chromosome 17q22 (Abbott et al. 1990).

Mendelian inheritance. Mendelian inheritance was confirmed in two large families.

Other comments. The polymorphism was detected through direct sequencing of all coding regions of the $H N F 1 B$ gene in an aboriginal Canadian with type 2 diabetes. Nucleotide 1968 is within the $3^{\prime}$-untranslated region of exon 9. Target DNA was amplified, using an initial melting temperature of $94^{\circ} \mathrm{C}$ for $5 \mathrm{~min}$, followed by 30 cycles of $94^{\circ} \mathrm{C}$ for $30 \mathrm{~s}, 57^{\circ} \mathrm{C}$ 


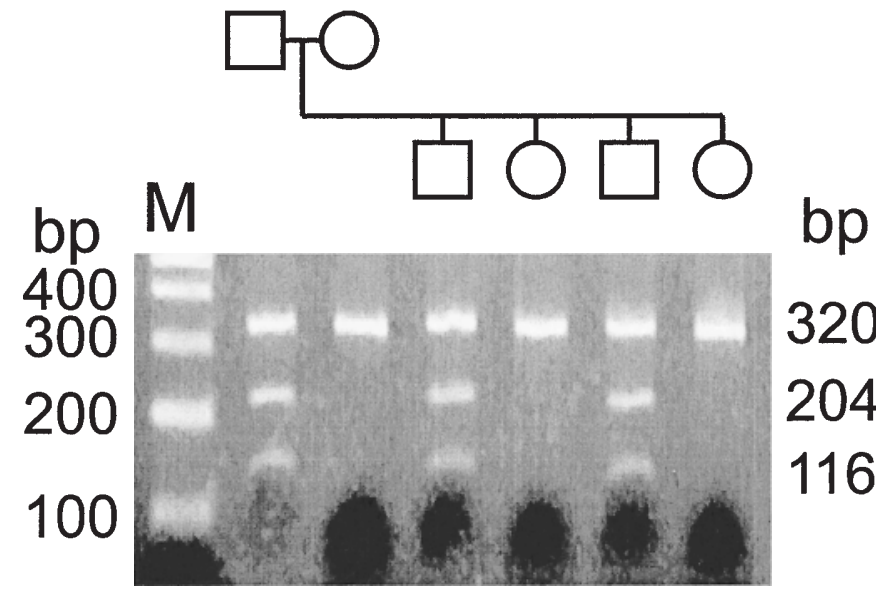

Fig. 1. MspI restriction fragment length polymorphism (RFLP) detecting $H N F 1 B$ 1968A/G polymorphism. MspI digests were electrophoresed in $2 \%$ agarose gels. Pedigree structure indicates familial relationships between samples. $M$ indicates molecular weight marker. Numerals on left side correspond to molecular weight marker band sizes. Numerals on right side correspond to fragment sizes

for $30 \mathrm{~s}$, and $72^{\circ} \mathrm{C}$ for $30 \mathrm{~s}$. A final $72^{\circ} \mathrm{C}$ extension step for $10 \mathrm{~min}$ terminated the process. The fragments were visualized in $2 \%$ agarose gels.
Table 1. Allele frequencies of $H N F 1 B$ 1968A/G polymorphism as detected by $M s p \mathrm{I}$

\begin{tabular}{lllll}
\hline & & & Frequency & \\
\cline { 3 - 5 } Allele & Nucleotide & Fragments (bp) & $\begin{array}{l}\text { Caucasian } \\
(\mathrm{n}=50)\end{array}$ & $\begin{array}{l}\text { Oji-Cree } \\
(\mathrm{n}=58)\end{array}$ \\
\hline $1968 \mathrm{~A}$ & $\mathrm{~A}$ & 320 & 0.940 & 0.871 \\
$1968 \mathrm{G}$ & $\mathrm{G}$ & $204+116$ & 0.060 & 0.129 \\
\hline
\end{tabular}

Acknowledgments This work was supported by the MRC Canada (MT13430), the Canadian Genetic Diseases Network, the Heart and Stroke Foundation of Ontario (CI2979), and the Blackburn Group.

\section{References}

Abbott C, Piaggio G, Ammendola R, Solomon E, Povey S, Gounari F, De Simone V, Cortese R (1990) Mapping of the gene TCF2 for the transcription factor LFB3 to human chromosome 17 by polymerase chain reaction. Genomics 8:165-167

Bach I, Mattei M-G, Cereghini S, Yaniv M (1991) Two members of an HNF1 homeoprotein family are expressed in human liver. Nucleic Acids Res 19:3553-3559

Horikawa Y, Iwasaki N, Hara M, Furuta H, Hinokio Y, Cockburn BN, Lindner T, Yamagata K, Ogata M, Tomonaga O, Kuroki H, Kasahara T, Iwamoto Y, Bell GI (1997) Mutation in hepatocyte nuclear factor-1-beta gene (TCF2) associated with MODY. Nature Genet 17:384-385 